\title{
Immobilization and Stabilization of Beta-Xylosidases from Penicillium janczewskii
}

\author{
César Rafael Fanchini Terrasan ${ }^{1,2}$ (D) \\ Maria Romero-Fernández ${ }^{1}$ (D) - Alejandro H. Orrego ${ }^{1}$ (D) \\ Sandro Martins Oliveira ${ }^{1}$ (D) Benevides Costa Pessela $^{3}$. \\ Eleonora Cano Carmona ${ }^{2}$ - José Manuel Guisan ${ }^{1}$
}

Received: 9 September 2016 / Accepted: 10 November 2016/

Published online: 23 November 2016

(C) Springer Science+Business Media New York 2016

\begin{abstract}
Xylosidases are critical for complete degradation of xylan, the second main constituent of plant cell walls. A minor $\beta$-xylosidase (BXYL II) from Penicillium janczewskii was purified by ammonium sulfate precipitation (30\% saturation) followed by DEAESephadex chromatography in $\mathrm{pH} 6.5$ and elution with $\mathrm{KCl}$. The enzyme presented molecular weight (MW) of $301 \mathrm{kDa}$ estimated by size exclusion chromatography. Optimal activity was observed in $\mathrm{pH} 3.0$ and $70-75^{\circ} \mathrm{C}$, with higher stability in $\mathrm{pH} 3.0-4.5$ and half-lives of 11,5 ,
\end{abstract}

Electronic supplementary material The online version of this article (doi:10.1007/s12010-016-2331-1) contains supplementary material, which is available to authorized users.

César Rafael Fanchini Terrasan

cesarterrasan@hotmail.com; https://www.researchgate.net/profile/Cesar_Rafael_Fanchini_Terrasan

Alejandro H. Orrego

a.herrera@csic.es

Benevides Costa Pessela

b.pessela@csic.es

Eleonora Cano Carmona

ecarmona@rc.unesp.br

José Manuel Guisan

jmguisan@icp.csic.es

1 Departamento de Biocatálisis, Instituto de Catálisis (ICP), Consejo Superior de Investigaciones Científicas (CSIC), Campus Universidad Autónoma de Madrid (UAM), Cantoblanco, Calle de Marie Curie, 28049 Madrid, Spain

2 Departamento de Bioquímica e Microbiologia, Instituto de Biociências, Univ Estadual Paulista (UNESP), Caixa Postal 199, Av. 24 A, 1515, Bela Vista, Rio Claro, SP 13506-900, Brazil

3 Departamento de Biotecnología y Microbiología de Alimentos, Instituto de Investigación en Ciencias de los Alimentos (CIAL), Consejo Superior de Investigaciones Científicas (CSIC), Campus Universidad Autónoma de Madrid (UAM), Cantoblanco, 28049 Madrid, Spain 
and 2 min at 65,70 , and $75^{\circ} \mathrm{C}$, respectively. Inhibition was moderate with $\mathrm{Pb}^{+2}$ and citrate and total with $\mathrm{Cu}^{+2}, \mathrm{Hg}^{+2}$, and $\mathrm{Co}^{+2}$. Partially purified BXYL II and BXYL I (the main $\beta$ xylosidase from this fungus) were individually immobilized and stabilized in glyoxyl agarose gels. At $65^{\circ} \mathrm{C}$, immobilized BXYL I and BXYL II presented half-lives of 4.9 and $23.1 \mathrm{~h}$, respectively, therefore being 12.3 -fold and 33 -fold more stable than their unipuntual $\mathrm{CNBr}$ derivatives (reference mimicking soluble enzyme behaviors). During long-term incubation in $\mathrm{pH} 5.0$ at $50{ }^{\circ} \mathrm{C}, \mathrm{BXYL}$ I and BXYL II glyoxyl derivatives preserved 85 and $35 \%$ activity after 25 and 7 days, respectively. Immobilized BXYL I retained $70 \%$ activity after 10 reuse cycles of $p$-nitrophenyl- $\beta$-D-xylopyranoside hydrolysis.

Keywords $\beta$-Xylosidases $\cdot$ Penicillium janczewskii $\cdot$ Enzyme purification $\cdot$ Enzyme characterization $\cdot$ Enzyme immobilization $\cdot$ Enzyme stabilization

$\begin{array}{ll}\text { Abbreviations } \\ p \text {-NPX } & p \text {-Nitrophenyl } \beta \text {-D-xylopyranoside } \\ \text { PEG } & \text { Polyethylene glycol } \\ \text { PEI } & \text { Polyethylenimine } \\ \text { SDS } & \text { Sodium dodecyl sulfate }\end{array}$

\section{Introduction}

The conversion of xylan into valuable products represents an important part of the effort to enable lignocellulose biomass processing in order to develop different ways in the manufacture of chemicals and renewable energy as well. Owing to its complex structure, the complete degradation of xylan demands numerous enzymes acting cooperatively. Among other enzymes from the xylanolytic complex, $\beta$-xylosidases (xylan 1,4-beta-xylosidase, EC 3.2.1.37) are exoglycosidases that hydrolyze non-reducing ends of xylooligosaccharides into xylose [1]. $\beta$ Xylosidases are critical for the complete degradation of xylans since they carry the greatest workload in relation to the number of cleaved glycosidic bonds, as well as in alleviating product inhibition of xylanases [2] and cellulases [3].

Interest in xylanolytic enzymes has increased in recent decades due to their applications in food, animal feed, pharmaceutical, and fuel and chemical industries. Notably, in processes in the pulp and paper and textile industries, cellulases must be absent in the enzymatic cocktail to preserve the cellulose fibers. A contemporary concern is the rational use of $\beta$-xylosidases in the complete hydrolysis of xylan to the final product, D-xylose, for their central role in many biotransformations [4-7].

Many fungal species are formidable sources of xylanolytic enzymes [8], and biomass degrading fungi rely on complex machineries that generally include both direct enzymatic depolymerization and also oxidative species [9]. After a new efficient producer is isolated, it is critical to purify and characterize the enzymatic constituents to comprehend their action towards substrates and their regulation and properties in order to develop more viable processes. Compared to free enzymes in solution, immobilized enzymes can be more robust and tolerant to environmental variations. Furthermore, the heterogeneity of immobilized systems permits easy recover of both biocatalyst and products, numerous re-use, continuous operation, rapid termination of reactions, and greater variety in bioreactor designs [10]. Immobilization of multimeric enzymes, such as many microbial $\beta$-xylosidases [11], can be a particular and complex problem in 
which subunit dissociation can result in inactivation and even product contamination [12]. Currently, there are some reports dealing with immobilization and stabilization of microbial xylanases through multipoint covalent attachments [13-15], although, to the best of our knowledge, only one $\beta$-xylosidase has been immobilized by this technique, demonstrating the suitability of this support for immobilization of such important enzymes [16].

A Penicillium janczewskii strain isolated from the Atlantic Rainforest (São Paulo, Brazil) is a good producer of xylanolytic enzymes, but not of cellulases $[17,18]$. The main extracellular $\beta$-xylosidase (BXYL I) produced in liquid cultures was purified and characterized as a $200 \mathrm{kDa}$ dimeric enzyme with identical subunits, presenting optimum activity in $\mathrm{pH} 4.0$ and at $75^{\circ} \mathrm{C}$ [19]. In another study, the crude xylanase, $\beta$-xylosidase, and $\alpha$-L-arabinofuranosidase were co-immobilized providing a biocatalyst active in the degradation of different arabinoxylans. In this preparation, the $\beta$-xylosidase was poorly stable under operational conditions [20]. In this work, we sought to purify and characterize a second extracellular $\beta$ xylosidase from $P$. janczewskii (BXYL II), which is present to a lesser extent in the culture filtrate. Besides, the immobilization of both $\beta$-xylosidases from this fungus was carried out aiming to obtain highly active and stable biocatalysts.

\section{Materials and Methods}

\section{Materials}

Agarose 4BCL was purchased from Agarose Bead Technologies (Madrid, Spain). pNitrophenyl- $\beta$-D-xylopyranoside, glycidol, potassium tetraborate tetrahydrate, sodium borohydride, sodium periodate, ethanolamine, Leuconostocc spp. dextran (molecular weight (MW) 15,000-25,000), polyethylenimine (PEI), and molecular weight standard proteins for electrophoresis and size exclusion chromatography were from Sigma-Aldrich Co. (St. Louis, MO, USA). Polyethylene glycol (PEG) was from Merck (Hohenbrunn, Germany). Cyanogen bromide (CNBr) Sepharose 4B was from GE Healthcare (Uppsala, Sweden). All reagents were analytical grade.

\section{Methods}

Results are mean of at least three experiments. Experimental error was $\leq 5 \%$.

\section{Strain Maintenance and Enzyme Production}

P. janczewskii (CRM 1348) is deposited at The Central of Microbial Resources, CMR-UNESP, São Paulo, Brazil. Maintenance and enzyme production were carried out as previously described [19]. After fungal growth, mycelium was removed by vacuum filtration, and the cleared supernatant obtained after centrifugation $\left(10,000 \times \mathrm{g}, 20 \mathrm{~min}, 4^{\circ} \mathrm{C}\right)$ was used as an enzyme source.

\section{Determination of Enzyme Activity and Protein}

$\beta$-Xylosidase activity was assayed using $5 \mathrm{mM} p$-nitrophenyl- $\beta$-D-xylopyranoside ( $p$ NPX) buffered solution [21]. BXYL I was assayed in $0.05 \mathrm{M}$ sodium acetate buffer $\mathrm{pH} 5.0$ and $\mathrm{BXYL}$ II in $0.05 \mathrm{M}$ glycine $\mathrm{HCl}$ buffer $\mathrm{pH}$ 3.0. At appropriate time intervals, aliquots were 
taken and the reaction was stopped with a saturated solution of sodium tetraborate. The released $p$-nitrophenolate was determined by reading absorbance at $405 \mathrm{~nm}$. Assays were performed in duplicate.

During enzyme purification, protein determination was performed by the Lowry method [22], using bovine serum albumin as standard.

\section{Enzyme Purification}

BXYL I was partially purified using ammonium sulfate precipitation and ion exchange chromatography, based on previous protocol [19]. Chromatography with CM Sephadex C50 was carried out in batch mode under mild agitation. After 3-h incubation, the supernatant was removed and adsorbed proteins were eluted with $0.05 \mathrm{M}$ sodium acetate buffer $\mathrm{pH} 5.7$ for additional $2 \mathrm{~h}$.

BXYL II was precipitated with ammonium sulfate to $35 \%$ saturation. After centrifugation $\left(10,000 \times g, 20 \mathrm{~min}, 4^{\circ} \mathrm{C}\right)$, the supernatant source of BXYL I was separated (see below) and the precipitate was suspended in $0.05 \mathrm{M}$ imidazole buffer $\mathrm{pH} 6.5$ and dialyzed against the same buffer $\left(6 \mathrm{~h}\right.$, three changes, $\left.4{ }^{\circ} \mathrm{C}\right)$. After dialysis, the sample was chromatographed on a DEAESephadex A-50 column $(1.4 \times 17 \mathrm{~cm})$ equilibrated in the same buffer, $1.2 \mathrm{ml} / \mathrm{min}$ flow rate and $3.5 \mathrm{ml}$ collected fractions. After washing the column with the same buffer, bound proteins were eluted with $100 \mathrm{ml}$ of $0-1.0 \mathrm{M}$ ascending $\mathrm{KCl}$ gradient prepared in the same buffer. Fractions with high $\beta$-xylosidase activity were pooled.

Partially purified BXYL I was employed for immobilization experiments. BXYL II was characterized in its free form and then immobilized. Purification was performed at $4{ }^{\circ} \mathrm{C}$, and at the end of each step, protein concentration and enzymatic activity in the resultant sample were determined. Prior to immobilization, samples were concentrated by overnight dialysis against a $20 \%(w / v)$ polyethylene glycol MW 35,000 solution.

\section{Determination of Molecular Weight by Size Exclusion Chromatography}

The MW of BXYL II was calculated based on elution volumes of proteins (Ve) and blue dextran (Vo) in a Sephadex G-200 column $(2.5 \times 64.0 \mathrm{~cm})$. Proteins were eluted with $0.05 \mathrm{M}$ ammonium acetate buffer $\mathrm{pH} 6.8$ at $0.3 \mathrm{ml} / \mathrm{min}$ flow rate and $3.0 \mathrm{ml}$ collected fractions. $\beta$ Amylase $(200 \mathrm{kDa})$, alcohol dehydrogenase $(150 \mathrm{kDa})$, bovine serum albumin $(66 \mathrm{kDa})$, carbonic anhydrase $(29 \mathrm{kDa})$, and cytochrome c $(12.4 \mathrm{kDa})$ were used as standard.

\section{Electrophoresis}

SDS-PAGE of the BXYL II sample from size exclusion chromatography was performed in 8$18 \%(w / v)$ gradient gel, and protein bands were stained with $0.1 \%(w / v)$ Coomassie brilliant blue R-250 [23]. Bovine carbonic anhydrase (29 kDa), egg albumin (45 kDa), bovine serum albumin $(66 \mathrm{kDa})$, rabbit phosphorylase b $(97 \mathrm{kDa})$, Escherichia coli $\beta$-galactosidase $(116 \mathrm{kDa})$, and myosin from rabbit muscle $(200 \mathrm{kDa})$ were used as standard.

\section{Preparation of Agarose-Based Supports and Dextran Oxidation}

Glyoxyl and monoaminoethyl- $N$-aminoethyl (MANAE) supports were prepared using 4\% cross-link agarose beads, according to Mateo et al. [24] and Fernandez-Lafuente et al. [25], 
respectively. After activation, the gels were washed with distilled water, vacuum dried (with the pores of agarose gels filled with water), and stored at $4{ }^{\circ} \mathrm{C}$. Fully oxidized Leuconostoc spp. dextran was prepared as previously described [26].

\section{Enzyme Immobilization}

Stability of BXYL I and BXYL II in pH 10 In order to establish the conditions for immobilization on glyoxyl supports, the use of low temperature and protecting agents was evaluated aiming to stabilize the enzymes in alkaline conditions. The enzymes were 2-fold diluted in $10 \mathrm{ml}$ of $0.2 \mathrm{M}$ sodium bicarbonate buffer $\mathrm{pH} 10.0$ containing 30 or $50 \%(\mathrm{w} / \mathrm{v})$ trehalose, glycerol, and polyethylene glycol MW 6000 or 35,000. Incubation was carried out at in an ice-cold bath and at $25{ }^{\circ} \mathrm{C}$. At different intervals, aliquots were withdrawn and the activity was assayed as described above. The immobilization protocol was further designed according to the stability of the soluble enzyme in the different conditions.

Immobilization on Glyoxyl Agarose BXYL I was 2-fold diluted in $0.2 \mathrm{M}$ sodium bicarbonate buffer $\mathrm{pH} 10.0$ containing 50\% ( $w / v$ ) PEG 35,000, to $10 \mathrm{ml}$ final volume, $4{ }^{\circ} \mathrm{C}$. The solution was added to $1.0 \mathrm{~g}$ of glyoxyl agarose support, and the suspension was gently stirred. The first immobilized derivative was prepared by carrying out immobilization for $2 \mathrm{~h}$ in an icecold bath. A second derivative was prepared by carrying out incubation initially in an ice-cold bath for $30 \mathrm{~min}$. Then, the system was removed from cold to let the temperature gradually increase up to room temperature for an additional $40 \mathrm{~min}$.

BXYL II immobilization was similar to described BXYL I; however, the $\mathrm{pH}$ was adjusted to 9.3-9.5 and contained 30\% ( $w / v)$ PEG 35,000. After ice-cold incubation, the temperature was allowed to increase for an additional $1 \mathrm{~h}$. A second derivative was prepared by carrying out overnight incubation $(17 \mathrm{~h})$ at room temperature.

After immobilization, the derivatives were reduced with $10 \mathrm{mg}$ of sodium borohydride for $30 \mathrm{~min}$ and then washed abundantly with water and vacuum filtered.

Immobilization on MANAE Agarose and Post-Immobilization Techniques BXYL II was 2-fold diluted in $0.05 \mathrm{M}$ sodium phosphate buffer $\mathrm{pH} 7.0$, to a $20 \mathrm{ml}$ final volume, $25^{\circ} \mathrm{C}$. The diluted enzyme solution was added to $2.0 \mathrm{~g}$ of MANAE-agarose support, and the suspension gently stirred for $30 \mathrm{~min}$ at $25{ }^{\circ} \mathrm{C}$. After this period, the derivative was washed abundantly with the same buffer and vacuum filtered.

Dextran-coated derivative: $0.5 \mathrm{~g}$ of MANAE-agarose derivative, was added to $5 \mathrm{ml}$ of fully oxidized dextran (as described above), $\mathrm{pH}$ adjusted to 7.0, and the suspension gently agitated at $25^{\circ} \mathrm{C}$. Incubation periods of $2 \mathrm{~h}$ and overnight were evaluated. Then, $5 \mathrm{ml}$ of $0.1 \mathrm{M}$ sodium bicarbonate buffer $\mathrm{pH} 10.0$ was added, and the derivatives were reduced with $5 \mathrm{mg}$ of sodium borohydride for $30 \mathrm{~min}$.

PEI-coated derivative: $0.5 \mathrm{~g}$ of MANAE-agarose derivative was added to $5 \mathrm{ml}$ of $50 \mathrm{~g} / \mathrm{l} \mathrm{PEI}$ MW 25,000 solution prepared in $0.025 \mathrm{M}$ sodium phosphate buffer $\mathrm{pH} 7.0$, and the suspension gently agitated at $25^{\circ} \mathrm{C}$. Incubation periods of $2 \mathrm{~h}$ and overnight were evaluated.

Glutaraldehyde-coated derivative: $0.5 \mathrm{~g}$ of MANAE-agarose derivative was added to $5 \mathrm{ml}$ of $5 \mathrm{~g} / \mathrm{l}$ glutaraldehyde solution, prepared in $0.025 \mathrm{M}$ sodium phosphate buffer $\mathrm{pH} 7.0$, and the suspension gently agitated at $25^{\circ} \mathrm{C}$. This treatment fully modifies the primary amino groups of the enzyme and the support with just one glutaraldehyde molecule [27, 28]. After $1 \mathrm{~h}$, the suspension was filtered and washed with the same buffer to remove the excess of 
glutaraldehyde. Additional buffered incubations for $2 \mathrm{~h}$ and overnight at $25{ }^{\circ} \mathrm{C}$ were evaluated in order to possibly achieve more intense enzyme-support cross-linking.

The derivatives were washed abundantly with water, filtered under vacuum, and stored at $4{ }^{\circ} \mathrm{C}$.

Immobilization on CNBr-Activated Sepharose BXYL I and BXYL II were 4-fold diluted in $0.1 \mathrm{M}$ sodium phosphate buffer $\mathrm{pH} 7.0$ and immobilized under mild agitation, $15 \mathrm{~min}, 4{ }^{\circ} \mathrm{C}$. The remaining reactive groups were blocked with ethanolamine, according to the supplier.

Immobilization Parameters Immobilization yield was defined as the ratio between activities in the final supernatant and in the blank of the soluble enzymes. Expressed activity was the ratio activity in the derivative suspension after immobilization and initial activity.

\section{Free Enzyme and Derivative Characterization}

Determination of Optima $\mathbf{p H}$ and Temperature Optimum $\mathrm{pH}$ for the free BXYL II was determined by performing enzyme assays in the $\mathrm{pH}$ range 3.0-8.0 using $0.05 \mathrm{M}$ glycine $\mathrm{HCl}$ buffer $\mathrm{pH}$ 2.0, 2.5, and 3.0 and McIlvaine buffer $\mathrm{pH} 3.0-6.0$, at $75^{\circ} \mathrm{C}$. Optimum temperature was determined by assaying activity in the $55-85^{\circ} \mathrm{C}$ range, using $0.05 \mathrm{M}$ glycine $\mathrm{HCl}$ buffer pH 3.0.

Enzymatic reactions with immobilized BXYL I and BXYL II on glyoxyl supports were carried out in $0.05 \mathrm{M}$ glycine $\mathrm{HCl}$ buffer $\mathrm{pH} 2.0$ and 3.0, $0.05 \mathrm{M}$ sodium acetate buffer $\mathrm{pH} 4.2$ and 5.0, and sodium phosphate buffer $\mathrm{pH} 6.0$ and 7.0 , at $75^{\circ} \mathrm{C}$. Optimum temperature was determined by assaying activity in the range from 60 to $85^{\circ} \mathrm{C}$, in $0.05 \mathrm{M}$ sodium acetate buffer $\mathrm{pH} 5.0$ for BXYL I and $0.05 \mathrm{M}$ glycine $\mathrm{HCl}$ buffer $\mathrm{pH} 3.0$ for BXYL II.

pH Stability Stability of free BXYL II at different $\mathrm{pH}$ was determined by incubating enzyme samples 1:2 $(\mathrm{v} / \mathrm{v})$ diluted in different buffers to compose a $\mathrm{pH}$ range of 2.0-6.0, using 0.05 glycine $\mathrm{HCl}$ buffer $\mathrm{pH}$ 2.0-3.0 and McIlvaine buffer $\mathrm{pH}$ 3.0-6.0. Incubation was carried out for $24 \mathrm{~h}$ at $4{ }^{\circ} \mathrm{C}$. Enzyme activity was assayed in $0.05 \mathrm{M}$ glycine $\mathrm{HCl}$ buffer $\mathrm{pH} 3.0$ at $75{ }^{\circ} \mathrm{C}$.

One gram of BXYL I and BXYL II glyoxyl derivatives was suspended in $10 \mathrm{ml}$ of different buffers to compose the $\mathrm{pH}$ range 4.0-9.0. The following $0.05 \mathrm{M}$ buffer systems were utilized: sodium acetate $\mathrm{pH} 4.2$ and 5.0, sodium phosphate $\mathrm{pH} 6.0$ and 7.0, and Tris $\mathrm{HCl} \mathrm{pH} 8.0$ and 9.0. The suspension was incubated at $50{ }^{\circ} \mathrm{C}$, and at several time points, samples were withdrawn and the activity was assayed. The remaining activity was calculated as the ratio between activity at a given time and the activity at the beginning of incubation.

Thermal Stability The free BXYL II was incubated without substrate at 65,70 , and $75{ }^{\circ} \mathrm{C}$. Aliquots were withdrawn at various time intervals for subsequent determination of residual activity. One gram of BXYL I and BXYL II glyoxyl derivatives was suspended in $10 \mathrm{ml}$ of different buffers at different $\mathrm{pH}$. Suspensions were incubated at different temperatures, and aliquots were withdrawn at various time intervals for subsequent determination of residual activity under the conditions stated above. The half-lives were calculated by the ratio of $\ln$ $2 / K_{\mathrm{d}}$. The inactivation constant $\left(K_{\mathrm{d}}\right)$ was determined by the equation: $\ln A=\ln A_{0}-K_{\mathrm{d}} \times t$, where $A_{0}$ and $A$ are, respectively, the initial activity and the activity after time $t(\mathrm{~h})$. 
Effect of Ions and SDS The influence of $\mathrm{CuCl}_{2}, \mathrm{ZnSO}_{4}, \mathrm{MnSO}_{4}, \mathrm{BaCl}_{2}, \mathrm{CaCl}_{2}, \mathrm{NH}_{4} \mathrm{Cl}$, $\mathrm{NaCl}, \mathrm{HgCl}_{2}, \mathrm{MgSO}_{4}, \mathrm{CoCl}_{2}$, sodium citrate, lead acetate, and SDS on the activity of the free BXYL II was evaluated by adding these substances to the enzymatic reactions at 2 and $10 \mathrm{mM}$ final concentrations. The results were expressed in relation to the control (no substance).

Catalyst Reuse Successive hydrolysis cycles of $3 \mathrm{mM} p$ NPX prepared in 0.05 M sodium acetate buffer $\mathrm{pH} 5.0$ were performed using BXYL I glyoxyl derivative at 1:10 proportion $(\mathrm{w} /$ v). Each cycle was carried out for $1 \mathrm{~h}$ at $50{ }^{\circ} \mathrm{C}$ under magnetic stirring $(300 \mathrm{rpm})$. At the end of each cycle, the derivative was vacuum filtered, washed with $0.05 \mathrm{M}$ sodium acetate buffer $\mathrm{pH}$ 5.0 and 1:10 $(w / v)$ re-suspended in the same buffer to measure residual activity (activity before the first cycle regarded as $100 \%$ ). It was then vacuum filtered again, and new substrate was added for the following cycle.

\section{Results and Discussion}

\section{Purification of the Minor $\beta$-Xylosidase from $P$. janczewskii}

A previous study purified and characterized the main $\beta$-xylosidase from this fungus (BXYL I) revealing the presence of a second $\beta$-xylosidase present in minor proportion in the crude extracellular extract [19]. The minor $\beta$-xylosidase from $P$. janczewskii (BXYL II) precipitated at $35 \%$ ammonium sulfate saturation, corresponding to $30 \%$ of the total activity. In the second purification step, the enzyme was submitted to anion exchange column chromatography in $\mathrm{pH}$ 6.5. Desorption of bound proteins was carried out with an ascending salt gradient. $\mathrm{KCl}$ was used since the enzyme was partially inactivated at high $\mathrm{NaCl}$ concentration. Most of the enzyme eluted with $0.65 \mathrm{M} \mathrm{KCl}$, while most of non-target proteins eluted at higher $\mathrm{KCl}$ concentration (not shown).

Table 1 summarizes the purification of BXYL II from P. janczewskii. Precipitation with ammonium sulfate rendered low purification, although it was used as the first step in the process due to its high yield and especially for allowing the separation, in distinct samples, of the two $\beta$-xylosidases produced by this fungus. The enzyme was 3 -fold purified, and the process presented $5.0 \%$ yield.

\section{Characterization of the Minor $\beta$-Xylosidase from $P$. janczewskii}

The sample from ion exchange chromatography was loaded into a size exclusion column eluting in a single sharp protein peak (not shown) with estimated native MW of $301 \mathrm{kDa}$, while some bands were observed on SDS-PAGE (Fig. 1), that may be attributed to contaminants eluting together with the enzyme due to its high MW. Probably, BXYL II is homotrimeric, with three $67 \mathrm{kDa}$ subunits, as verified by the presence of a more intense band. The MW of BXYL II is similar to many fungal $\beta$-xylosidases which usually present MW above $100 \mathrm{kDa}$ [29-33] but present MW higher than that of the BXYL I, whose native $\mathrm{MW}$ is $200 \mathrm{kDa}$ [19].

BXYL II was highly active in acid $\mathrm{pH}$, with optimal activity in $\mathrm{pH}$ 2.5-3.0. Intermediate activity values were observed in the $\mathrm{pH}$ range 3.5-5.0. In $\mathrm{pH} 2.0$ or above $\mathrm{pH} 5.0$, the activity decreased to lower levels. The enzyme presented high stability in the $\mathrm{pH}$ 
Table 1 Purification of BXYL II from P. janczewskii

\begin{tabular}{llllll}
\hline Step & $\begin{array}{l}\text { Total activity } \\
(\mathrm{U})\end{array}$ & Protein (mg) & $\begin{array}{l}\text { Specific activity } \\
\text { (U/mg prot.) }\end{array}$ & Yield (\%) & $\begin{array}{l}\text { Purification } \\
\text { (fold) }\end{array}$ \\
\hline $\begin{array}{l}\text { Crude filtrate } \\
\begin{array}{l}\text { Precipitate of 35\% ammonium } \\
\quad \text { sulfate saturation }\end{array}\end{array}$ & 3.8 & 91.8 & 0.1 & 100 & 1.0 \\
$\begin{array}{l}\text { DEAE-Sephadex A-50 pH 6.5 } \\
\text { DEA }\end{array}$ & 0.6 & 67.4 & 0.1 & 31.4 & 0.5 \\
\hline
\end{tabular}

$\beta$-Xylosidase activity was assayed in $0.05 \mathrm{M}$ glycine $\mathrm{HCl}$ buffer $\mathrm{pH} 3.0$ at $75^{\circ} \mathrm{C}$

range $3.0-4.5$, in which $80 \%$ of activity was retained. Intermediate activity values were observed in $\mathrm{pH} 2.0,2.5,5.0$, and 5.5, and in $\mathrm{pH} 6.0$, only $30 \%$ activity was verified (Fig. 2a). The wide $\mathrm{pH}$ range in which the enzyme was stable, especially considering the 3.0-4.5 range, in which the enzyme presented high activity and stability, allows its application for prolonged periods in different process.

High activity was verified between 70 and $80{ }^{\circ} \mathrm{C}$, with the optimum at $70-75{ }^{\circ} \mathrm{C}$. Below 70 or above $85{ }^{\circ} \mathrm{C}$, the activity decreased to less than $60 \%$ of the maximum (Fig. 2b). BXYL II presented optimal activity in slightly more acidic $\mathrm{pH}$ than BXYL I, that presents optimum activity in $\mathrm{pH} 5.0$ [19]. Both $\beta$-xylosidases showed optimal activity at the same temperature, which is quite high, considering that they were produced by a mesophilic microorganism. Optimum activity in acid $\mathrm{pH}$ is a common feature of most fungal $\beta$-xylosidases [11]. Nevertheless, optimum activity at such high temperatures has not been reported for $\beta$-xylosidases from other Penicillium species, only for $\beta$-xylosidases from thermotolerant fungi such as Aspergillus phoenicis [34], Aspergillus japonicus [30], and Aspergillus fumigatus [35]. Activity at high temperatures is important, especially for application in processes requiring high temperatures in the pulp and paper industry and in baking, among others.

The estimated half-lives of BXYL II were 11, 5, and $2 \mathrm{~min}$ at 65,70 , and $75{ }^{\circ} \mathrm{C}$, respectively (Fig. 3). BXYL I from $P$. janczewskii is slightly more stable than BXYL II presenting half-lives of 11 and 3 min at 70 and $75^{\circ} \mathrm{C}$, respectively [19].

Most of the evaluated ions presented no effect on the BXYL II from P. janczewskii. None of them activated the enzyme, whereas inhibition, at different levels, occurred in

Fig. 1 SDS-PAGE of BXYL II from $P$. janczewskii. Sample eluted from DEAE-Sephadex ion exchange chromatography (lane 1); molecular weight protein standards were bovine carbonic anhydrase (29 kDa), egg albumin (45 kDa), bovine albumin $(66 \mathrm{kDa})$, rabbit phosphorylase b $(97 \mathrm{kDa})$, E. coli $\beta$-galactosidase $(116 \mathrm{kDa})$, and rabbit muscle myosin $(200 \mathrm{kDa})$ (lane 2)

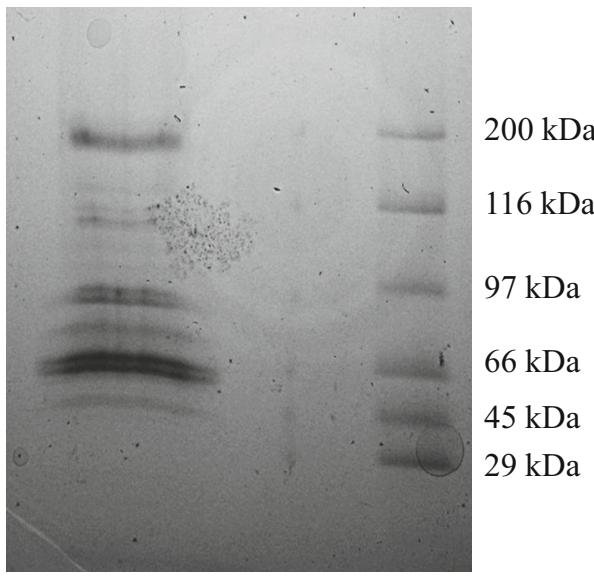


Fig. 2 Effect of $\mathrm{pH}$ (a) and temperature (b) on the free BXYL II from $P$. janczewskii. a Optimum activity (full lines) was determined by assaying enzyme activity in $0.05 \mathrm{M}$ glycine $\mathrm{HCl}$ buffer $\mathrm{pH}$ 2.0-3.0 and McIlvaine buffer $\mathrm{pH}$ from 3.0 to 6.0 at $75^{\circ} \mathrm{C}$. Stability (dashed line) was evaluated by 1:2 $(v / v)$ diluting the enzyme in 0.05 glycine $\mathrm{HCl}$ buffer $\mathrm{pH}$ 2.0-3.0 and McIlvaine buffer pH 3.0-6.0. Incubation was carried out for $24 \mathrm{~h}$ at $4{ }^{\circ} \mathrm{C}$, and then, activity was assayed in $0.05 \mathrm{M}$ glycine $\mathrm{HCl}$ buffer $\mathrm{pH} 3.0$ at $75^{\circ} \mathrm{C}$. b Enzyme activity was assayed in $0.05 \mathrm{M}$ glycine $\mathrm{HCl}$ buffer $\mathrm{pH}$ 3.0. $\beta$ Xylosidase activity (\%) (squares)

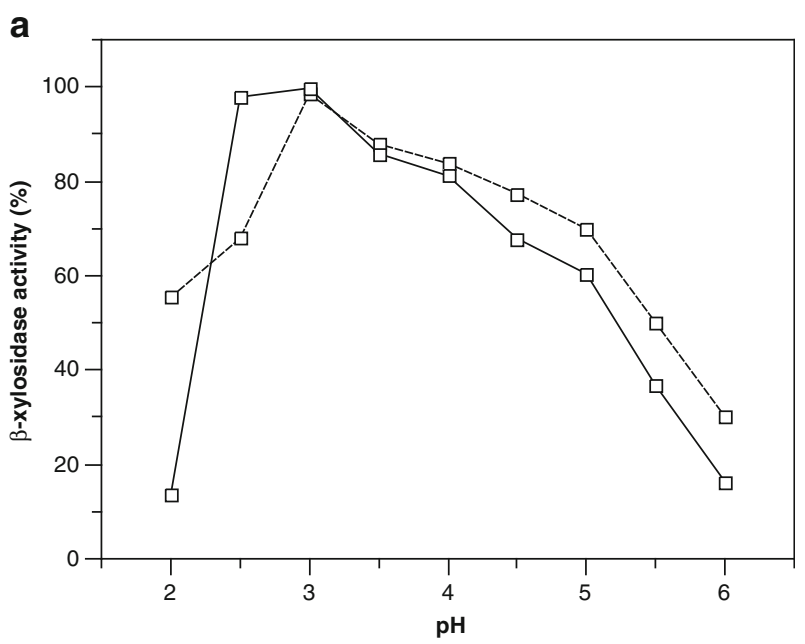

b

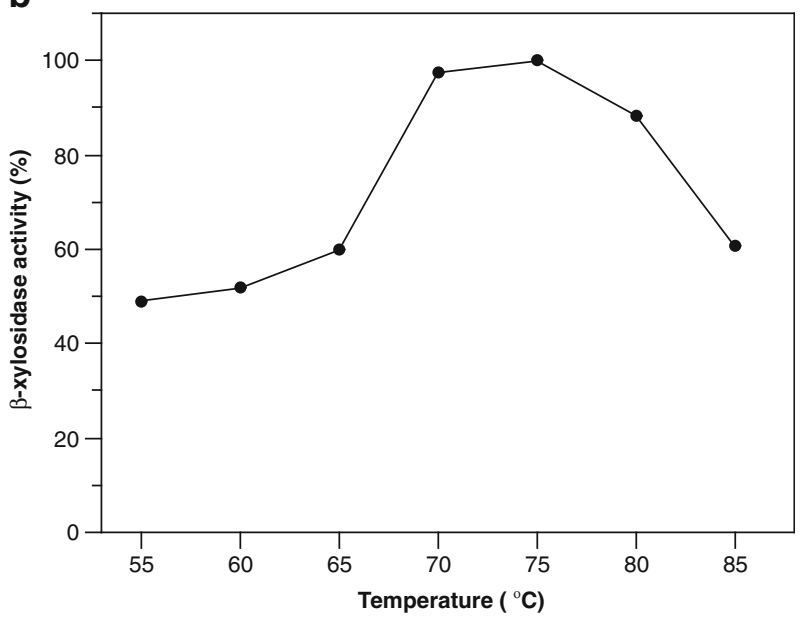

some cases: $\mathrm{ZnSO}_{4}$ and $\mathrm{Pb}\left(\mathrm{CH}_{3} \mathrm{COO}\right)_{2}$ at 2 or $10 \mathrm{mM}$ weakly inhibited $(\approx 10-15 \%$ inhibition) the enzyme; $\mathrm{CuCl}_{2}$ presented moderate effect at $2 \mathrm{mM}(\approx 25 \%$ inhibition $)$ and at $10 \mathrm{mM}$ completely inhibited the enzyme. At $10 \mathrm{mM}$, sodium citrate moderately inhibited the enzyme $(\approx 35 \%)$, whereas $\mathrm{CoCl}_{2}$ and $\mathrm{HgCl}_{2}$ were strong inhibitors, completely depleting its activity. Moderate inhibition by $\mathrm{ZnSO}_{4}, \mathrm{CoCl}_{2}$, and sodium citrate is also observed for BXYL I, but lead acetate has no effect on this enzyme. Inhibition by $\mathrm{CuCl}_{2}$ and $\mathrm{HgCl}_{2}$ also occurs with BXYL I, although it is more susceptible to $\mathrm{HgCl}_{2}$, being completely inhibited at $2 \mathrm{mM}$, and more resistant to $\mathrm{CuCl}_{2}$, being only partially inhibited at $10 \mathrm{mM}$ [19]. Inhibition by $\mathrm{Hg}^{2+}$ is not a general rule for $\beta$ xylosidases, and this effect was observed for the four purified $\beta$-xylosidases from $P$. wortmanni [36] and that from Aspergillus nidulans [37] but not for that from $P$. sclerotiorum [31]. BXYL II lost $25 \%$ activity with $2 \mathrm{mM}$ SDS, and it was completely denatured at $10 \mathrm{mM}$. Activity loss in the presence of detergent indicates the importance of hydrophobic interactions to maintain the three-dimensional structure of the enzyme. 
Fig. 3 Thermal inactivation course of free BXYL II from $P$. janczewskii. Enzyme activity was assayed in $0.05 \mathrm{M}$ glycine $\mathrm{HCl}$ buffer $\mathrm{pH} 3.0$ at $75^{\circ} \mathrm{C}$. $\beta$ Xylosidase activity $(\%)$ after incubation at 65 (circles), 70 (squares), and $75{ }^{\circ} \mathrm{C}$ (triangles)

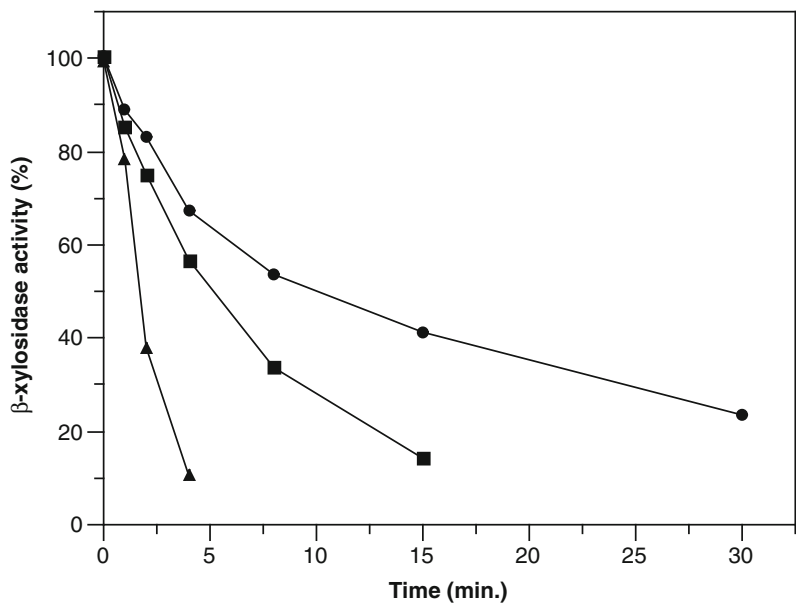

\section{Enzyme Immobilization}

Different catalysts of BXYL I and BXYL II from P. janczewskii were prepared by using differently activated agarose supports and variable immobilization strategies, i.e., irreversible covalent immobilization on glyoxyl agarose and also reversible anionic immobilization on MANAE agarose (that can further become irreversible in the case of glutaraldehyde cross-linking). The thermal stabilities of these derivatives could be compared to each other and to those of the free enzyme and of the $\mathrm{CNBr}$ agarose derivative. $\mathrm{CNBr}$ derivatives were the controls, since they were prepared under very mild conditions, not allowing multipoint immobilization, but only by very reactive $\mathrm{N}$ terminal. As a result, this derivative is reasonably similar to the free enzyme in its physico-chemical properties; however, to be bonded in a porous support, it has the advantage of not being susceptible to aggregation, hydrophobic interaction, etc., as opposition to the soluble protein [38].

\section{Immobilization of BXYL I from $P$. janczewskii}

Due to the low stability at $\mathrm{pH} 10.0$, which is a required condition to immobilize on glyoxyl-activated supports, the use of low temperature and different substances was evaluated as protecting agents, stabilizing enzyme structure in this condition. When incubation was performed in an ice-cold bath, trehalose had no protective effect and glycerol presented an intermediate effect, sustaining 50\% activity after 3-h incubation. Nevertheless, under room temperature, glycerol had no stabilizing effect, resulting in rapid depletion of enzyme activity (not shown). PEG was more efficient in stabilizing BXYL I. During ice-cold incubation, the enzyme slowly lost activity with almost no difference in stability verified among PEG of low or high MW. During incubation at room temperature, PEG MW 35,000 had a slightly more pronounced protective effect than PEG MW 6000 (S. 1).

Considering the high enzyme stability with PEG 35,000, in a first trial, immobilization was fully performed in an ice-cold bath (not shown). Nevertheless, the thermostability of this derivative was low (as presented below). Then, a second derivative was 
prepared by carrying out immobilization initially with incubation in an ice-cold bath for $0.5 \mathrm{~h}$; the suspension was subsequently removed from the cold, allowing the temperature to gradually increase to room temperature for an additional $1 \mathrm{~h}(\mathrm{~S} .2)$. Thus, the final protocol involved two steps, the first at low temperature in which most of the enzyme became attached to the support and then a second with gradual temperature increase. The process presented $100 \%$ yield and the derivative $78 \%$ expressed activity. BXYL I immobilization on CNBr Sepharose presented $67 \%$ yield and the derivative $60 \%$ expressed activity.

\section{Immobilization of BXYL II from $P$. janczewskii}

Ionic immobilization of BXYL II on MANAE agarose rendered $92 \%$ yield in relation to the enzymatic activity. Immobilization activated the immobilized enzyme, and the expressed activity increased to $133 \%$. In an attempt to fully stabilize the enzyme structure, this derivative was cross-linked with glutaraldehyde, polyethylenimine, and aldehyde-dextran at different conditions, which, at different levels, negatively influenced enzyme activity (Table 2).

Similarly to what was observed with BXYL I, the BXYL II also presented low stability in $\mathrm{pH}$ 10.0. Thus, immobilization of BXYL II on glyoxyl support followed a similar protocol to that established for BXYL. Immobilization, however, was carried out in $\mathrm{pH}$ 9.3-9.5, and the buffer contained a lower PEG concentration in order to avoid protein precipitation. Two glyoxyl derivatives were prepared, i.e., after the first stage of ice-cold incubation, immobilization was carried out for an additional 1.5 or $18 \mathrm{~h}$, considering that long-term incubation could increase enzyme-support attachment, possibly rendering higher stability to the immobilized enzyme. After $0.5 \mathrm{~h}$, no activity was detected in the supernatant and the derivatives with immobilization carried out for 1.5 or 17-h incubation presented 78 and 60\% expressed activity, respectively. Immobilization of BXYL II on CNBr Sepharose resulted in $73.5 \%$ yield and the derivative expressed $63 \%$ activity.

Table 2 Post-immobilization strategies evaluated on MANAE derivative of BXYL II from P. janczewskii

\begin{tabular}{|c|c|c|c|}
\hline \multicolumn{2}{|l|}{ Strategy } & \multirow{2}{*}{$\begin{array}{l}\text { Expressed } \\
\text { activity }(\%)\end{array}$} & \multirow[t]{2}{*}{ Half-life (h) } \\
\hline Coating/cross-linking substance & Incubation condition & & \\
\hline \multirow[t]{2}{*}{ None } & - & 133 & 1.0 \\
\hline & $1 \mathrm{~h}, \mathrm{pH} 7$, and $25^{\circ} \mathrm{C}$ & 38 & $\mathrm{NE}$ \\
\hline \multirow[t]{2}{*}{ Glutaraldehyde (5 g/l) } & Additional $2 \mathrm{~h}, \mathrm{pH} 7,25^{\circ} \mathrm{C}$ & 57 & 0.8 \\
\hline & $\begin{array}{l}\text { Additional overnight incubation, } \\
\text { pH } 7,25^{\circ} \mathrm{C}\end{array}$ & 57 & $\mathrm{NE}$ \\
\hline \multirow[t]{2}{*}{ Polyethylenimine MW 25,000 (50 g/l) } & $2 \mathrm{~h}, \mathrm{pH} 7,25^{\circ} \mathrm{C}$ & 34 & 0.8 \\
\hline & $\begin{array}{l}\text { Additional overnight incubation, } \\
\mathrm{pH} 7,25^{\circ} \mathrm{C}\end{array}$ & 10 & $\mathrm{NE}$ \\
\hline \multirow{2}{*}{$\begin{array}{l}\text { Dextran MW 15,000-25,000 } \\
\quad \text { (fully oxidized) }\end{array}$} & $2 \mathrm{~h}, \mathrm{pH} 7,25^{\circ} \mathrm{C}$ & 41 & 0.5 \\
\hline & $\begin{array}{l}\text { Additional overnight incubation, } \\
\text { pH } 7,25^{\circ} \mathrm{C}\end{array}$ & 10 & $\mathrm{NE}$ \\
\hline
\end{tabular}

$\beta$-Xylosidase activity was assayed in $0.05 \mathrm{M}$ Tris $\mathrm{HCl}$ buffer $\mathrm{pH} 3.0$ at $25^{\circ} \mathrm{C}$

$N E$ not evaluated 


\section{Characterization of BXYL I and BXYL II Derivatives}

After establishment of the immobilization protocols, glyoxyl and $\mathrm{CNBr}$ derivatives were characterized in relation to thermal and $\mathrm{pH}$ stability and optimal $\mathrm{pH}$ and temperature.

\section{Thermostability and Stability to $\mathrm{pH}$}

Stability at high temperature and in different $\mathrm{pH}$ is a very important aspect in enzymatic processes since the use of enzymes in industrial processes can be hindered by inactivation problems. Furthermore, the use of high temperature can contribute to avoid microbial contamination during the process.

When incubated at different temperatures and in pH 5.0 (Fig. 4), the BXYL I glyoxyl derivative (immobilization carried out initially in an ice-cold bath followed by temperature increase) was very stable up to $60{ }^{\circ} \mathrm{C}$. At $70{ }^{\circ} \mathrm{C}$, after $4 \mathrm{~h}$ of incubation, approximately $60 \%$ activity was retained, with half-life between 8 and $24 \mathrm{~h}$. At $50{ }^{\circ} \mathrm{C}$, this derivative still exhibited more than $75 \%$ activity even after 30 -day incubation, while at $80{ }^{\circ} \mathrm{C}$, all the activity was totally depleted after $30 \mathrm{~min}$ (not shown). On the other hand, the thermostability of the derivative for which immobilization was performed only in an ice-cold bath was much lower (half-life lower than $1 \mathrm{~h}$ at $70^{\circ} \mathrm{C}$ ) than that of the derivative obtained by following the two-stage protocol. This result clearly demonstrates that a higher temperature is necessary to increase the covalent bonds between the protein and the activated groups of the support, stabilizing its structure and providing much more thermostability to the immobilized enzyme.

The stability of the BXYL I glyoxyl derivative was evaluated in the $\mathrm{pH}$ range 4.0-9.0 at $50{ }^{\circ} \mathrm{C}$ (Fig. 5). The enzyme was stabilized in all $\mathrm{pH}$, presenting residual activity above $60 \%$ even after 24-h incubation. In pH 9.0, the enzyme was somehow more stable, retaining about $90 \%$ activity during the entire assay period.

BXYL II glyoxyl derivatives were also incubated under different conditions, presenting high stability up to $60^{\circ} \mathrm{C}$ and also in wide $\mathrm{pH}$ range, similarly to that verified for the BXYL I. During long-term incubation in $\mathrm{pH} 5.0$ and $50{ }^{\circ} \mathrm{C}$, this derivative retained $35 \%$ of the activity after 7 days (not shown).

Fig. 4 Thermal inactivation of immobilized BXYL I from $P$. janczewskii. Immobilization on glyoxyl support was carried out initially at low temperature in an ice-cold bath followed by temperature increase (full lines) and only at low temperature (dashed lines). Incubation was carried out in $0.05 \mathrm{M}$ sodium acetate buffer $\mathrm{pH}$ 5.0 , and the activity was performed in same buffer at $25^{\circ} \mathrm{C}$. $\beta$ Xylosidase activity (\%) of glyoxyl derivatives incubated at 50 (circles), 60 (squares), and $70{ }^{\circ} \mathrm{C}$ (diamonds)

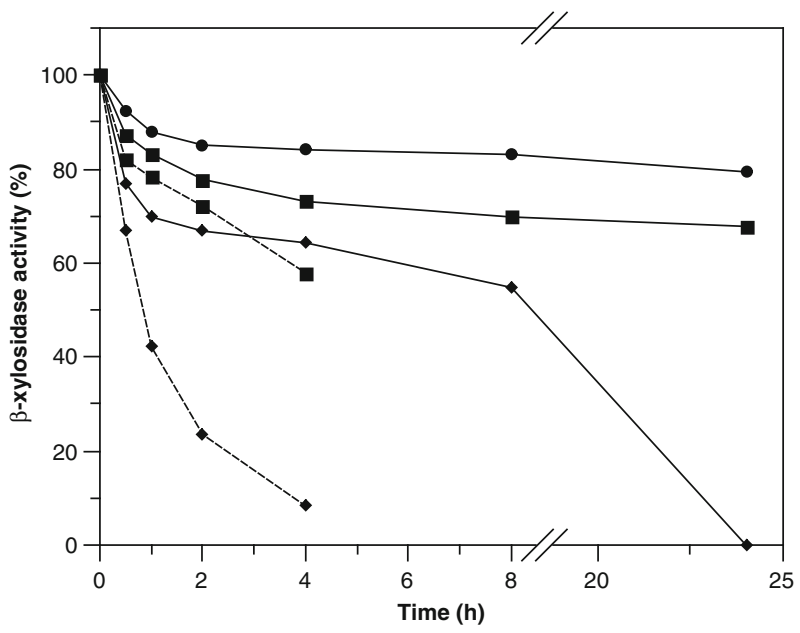


Fig. 5 Stability in different $\mathrm{pH}$ at $50^{\circ} \mathrm{C}$ of immobilized BXYL I from P. janczewskii. BXYL I glyoxyl derivative was incubated in $0.05 \mathrm{M}$ sodium acetate buffer $\mathrm{pH} 4.2$ and 5.0, 0.05 M sodium phosphate buffer $\mathrm{pH} 6.0$ and 7.0, and $0.05 \mathrm{M}$ Tris $\mathrm{HCl}$ buffer $\mathrm{pH} 8.0$ and 9.0. The activity was carried out in $0.05 \mathrm{M}$ sodium acetate buffer $\mathrm{pH}$ 5.0.

Residual $\beta$-xylosidase activity (\%) after incubation in $\mathrm{pH} 4.2$ (circles), 5.0 (squares), 6.0 (diamonds), 7.0 (triangles), 8.0 (inverted triangles), and (right-pointing triangles) 9.0

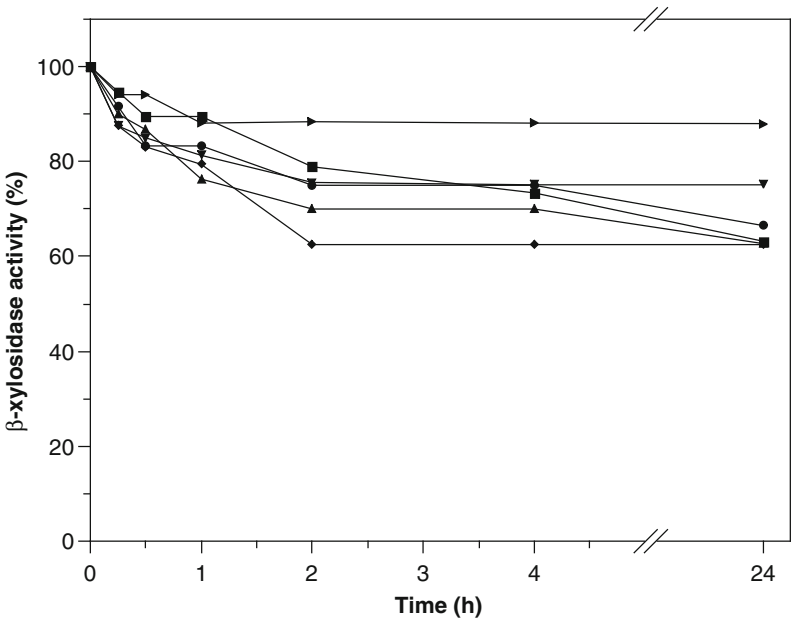

Comparing both BXYL II glyoxyl derivatives under incubation in $\mathrm{pH} 3.0$ and at $65^{\circ} \mathrm{C}$, the glyoxyl derivative for which immobilization was carried out for $1.5 \mathrm{~h}$ reached higher stabilization. Long-term immobilization $(17 \mathrm{~h})$ did not increase enzyme stability. On the contrary, the stability was even reduced, i.e., the derivative prepared under 1.5 -h incubation presented a halflife of $3.2 \mathrm{~h}$, while that obtained after 17-h incubation presented a half-life of $1.3 \mathrm{~h}$ (Fig. 6).

MANAE derivatives of BXYL II incubated in $\mathrm{pH} 3.0$ at $65{ }^{\circ} \mathrm{C}$ presented lower stabilities (Table 2). The half-life times of PEI-cross-linked and glutaraldehyde-crosslinked derivatives were both $0.8 \mathrm{~h}$ and that of the dextran-coated derivative was $0.5 \mathrm{~h}$, lower than that of the uncoated MANAE derivative $(1 \mathrm{~h})$. In this sense, the glyoxyl derivative, for which immobilization was carried out for $1.5 \mathrm{~h}$ was considered the best BXYL II derivative and then further characterized.

When the stability of BXYL I and BXYL II glyoxyl derivatives was evaluated at high temperature and in different $\mathrm{pH}$ (Fig. 7), a similar inactivation pattern was observed for both immobilized enzymes, i.e., the highest stability was verified in $\mathrm{pH} 5.0$, intermediate stability in $\mathrm{pH} 3.0$, and the lowest stability in $\mathrm{pH}$ 7.0. Comparing both derivatives,

Fig. 6 Thermal inactivation of immobilized BXYL II from P. janczewskii. Immobilization on glyoxyl support was carried out initially at low temperature, and then, the temperature was allowed to increase during 1.5 and $17 \mathrm{~h}$. Incubation was carried out in $0.05 \mathrm{M}$ glycine $\mathrm{HCl}$ buffer $\mathrm{pH}$ 3.0 at $65^{\circ} \mathrm{C}$, and the activity was performed in same buffer at $25^{\circ} \mathrm{C}$. $\beta$-Xylosidase activity $(\%)$ of glyoxyl derivative prepared by 1.5 (circles) and 17-h incubation (squares)

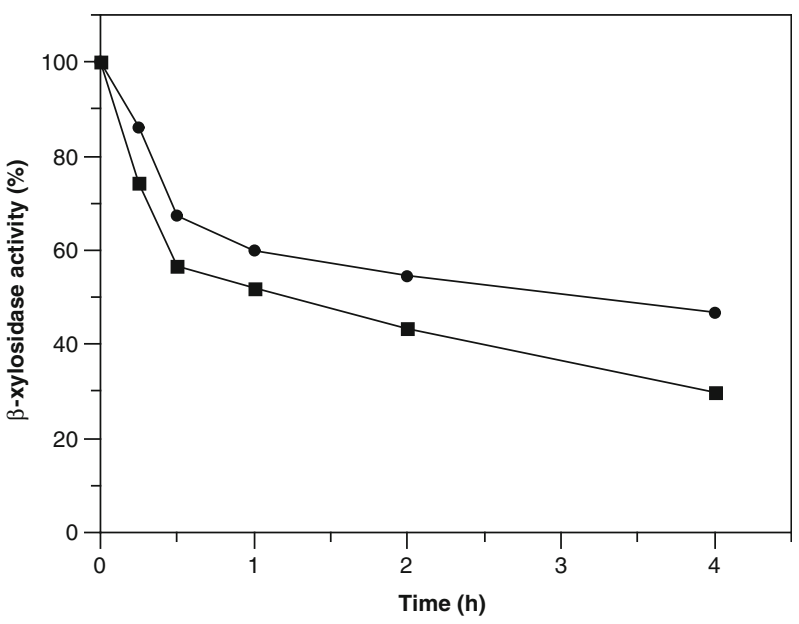


immobilized BXYL II was more stable than BXYL I in all $\mathrm{pH}$ values. The half-lives at $65^{\circ} \mathrm{C}$ in $\mathrm{pH} 5.0,3.0$, and 7.0 corresponded, respectively, to 4.9, 0.7, and $0.2 \mathrm{~h}$ for BXYL I and 23.1, 7.0, and $0.8 \mathrm{~h}$ for BXYL II.

$\mathrm{CNBr}$ derivatives incubated in $\mathrm{pH} 5.0$ and $65^{\circ} \mathrm{C}$ presented half-lives of 0.4 and $0.7 \mathrm{~h}$, for BXYL I and BXYL II, respectively. BXYL I and BXYL II glyoxyl derivatives were therefore 12.3-fold and 33-fold stabilized in relation to their $\mathrm{CNBr}$ derivatives, respectively. Compared to the free enzyme, the BXYL II glyoxyl derivative was 128 -fold thermostabilized. Furthermore, both BXYL I and BXYL II glyoxyl derivatives were more thermostable than the PEIcoated glyoxyl derivative of commercial $\beta$-xylosidase from Selenomonas ruminantium that presented half-life of $0.7 \mathrm{~h}$ at $55^{\circ} \mathrm{C}$ [16].

\section{Optima pH and Temperature}

The activity profiles in different $\mathrm{pH}$ or temperatures showed that the immobilized enzymes retained their properties, i.e., activity in acid $\mathrm{pH}$ and at elevated temperature (Fig. 8). In

Fig. $7 \mathrm{pH}$ stability of immobilized BXYL I (a) and BXYL II (b) from P. janczewskii. The derivatives were incubated in $0.05 \mathrm{M}$ Gly $\mathrm{HCl}$ buffer $\mathrm{pH} 3.0$, $0.05 \mathrm{M}$ sodium acetate buffer $\mathrm{pH}$ 5.0 , and $0.05 \mathrm{M}$ sodium phosphate buffer $\mathrm{pH} 7.0$ at $65^{\circ} \mathrm{C}$. $\beta$ -

Xylosidase activity (\%) of glyoxyl derivatives incubated in $\mathrm{pH} 3.0$ (circles), 5.0 (squares), and 7.0 (triangles) (full lines). Residual $\beta$ xylosidase activity (\%) of $\mathrm{CNBr}$ derivatives incubated in $\mathrm{pH} 5.0$ (inverted triangles) (dashed line)
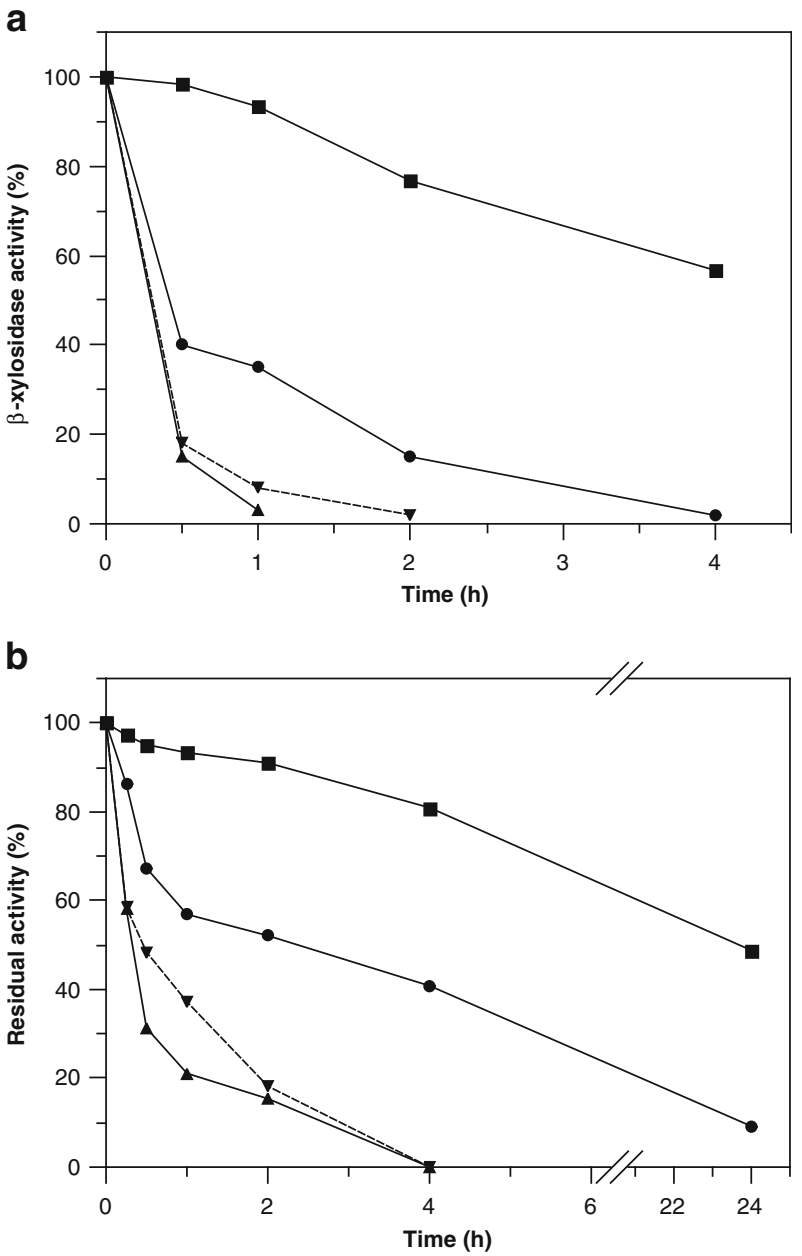
Fig. 8 Effect of $\mathrm{pH}$ (a) and temperature (b) on the activity of immobilized BXYL I and BXYL II from $P$. janczewskii. Enzyme activity was carried out in $0.05 \mathrm{M}$ glycine $\mathrm{HCl}$ buffer $\mathrm{pH} 2.0$ and 3.0, $0.05 \mathrm{M}$ sodium acetate buffer $\mathrm{pH}$ 4.2 and 5.0, and sodium phosphate buffer $\mathrm{pH} 6.0$ and 7.0 at $75^{\circ} \mathrm{C}(\mathbf{a})$ and in $0.05 \mathrm{M}$ sodium acetate buffer $\mathrm{pH} 5.0$ for BXYL I and $0.05 \mathrm{M}$ glycine $\mathrm{HCl}$ buffer $\mathrm{pH} 3.0$ for BXYL II (b). $\beta$-Xylosidase activity (\%) of derivatives BXYL I glyoxyl (filled squares), BXYL I $\mathrm{CNBr}$ (empty squares), BXYL II glyoxyl (filled triangles), and BXYL II CNBr (empty triangles)

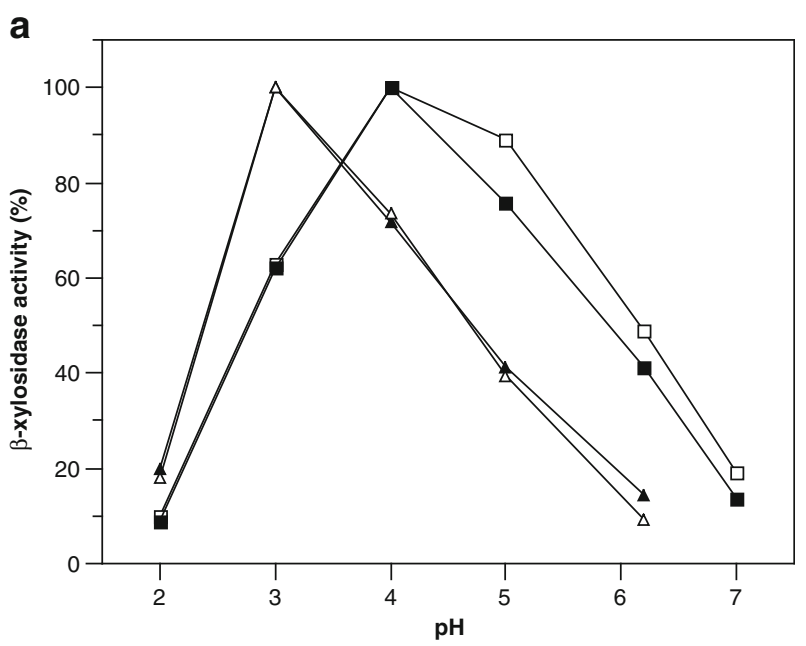

b

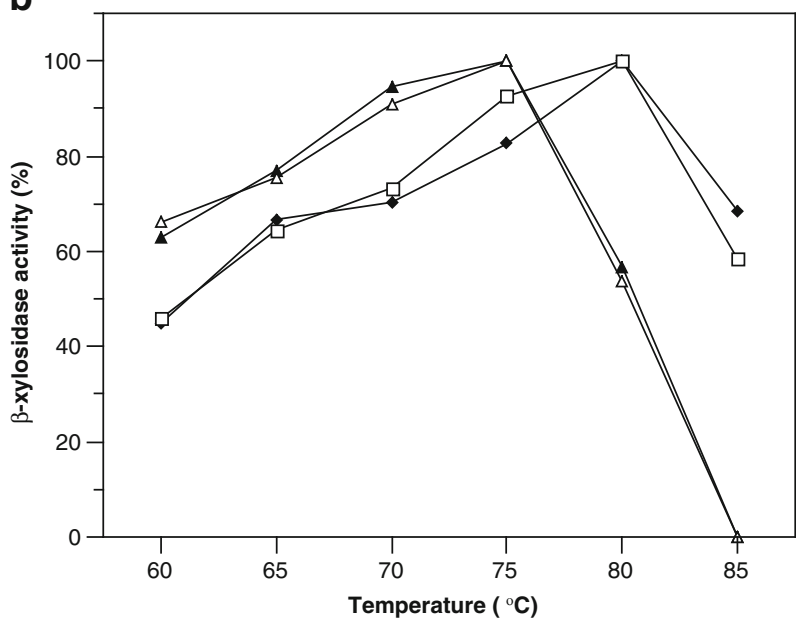

relation to the free enzyme [19], immobilized BXYL I was active in a slightly more acid condition with optimum activity in $\mathrm{pH} 4.0$ and also showed increase in optimum temperature from 75 to $80{ }^{\circ} \mathrm{C}$. Immobilized BXYL II retained exactly the same properties of the free enzyme with optimal activity in $\mathrm{pH} 3.0$ and at $70-75^{\circ} \mathrm{C}$.

\section{Reuse Cycles}

Considering that BXYL I is present in higher proportion in the crude extracellular extract and also its prolonged stability in $\mathrm{pH} 5.0$ and at $50{ }^{\circ} \mathrm{C}$ in the immobilized form, the stability of the BXYL I glyoxyl derivative was evaluated during successive operational cycles of $p$ NPX hydrolysis. The derivative retained $100 \%$ activity during five cycles, and after ten cycles, $70 \%$ of the activity was observed (not shown). This derivative was more stable than the glyoxyl derivative of $S$. ruminantium $\beta$-xylosidase, which presented $39 \%$ residual activity during eight $p$ NPX hydrolysis cycles [16], that may be attributed to the less BXYL I subunits 
(two subunits), while $S$. ruminantium $\beta$-xylosidase is tetrameric [39]. Moreover, due to its high operational stability, this derivative can be potentially used to complement the derivative containing the co-immobilized xylanase, $\beta$-xylosidase, and $\alpha$-L-arabinofuranosidase from P. janczewskii, because the $\beta$-xylosidase is faintly stable in this biocatalyst [20].

\section{Conclusions}

The minor $\beta$-xylosidase from $P$. janczewskii shares some properties with the main $\beta$ xylosidase from this fungus, such as activity in moderately acid $\mathrm{pH}$ and at high temperatures. Despite their low stability in $\mathrm{pH} 10.0$, both $\beta$-xylosidases can be stabilized at this condition and successfully immobilized by multipoint covalent immobilization on highly activated glyoxyl agarose gels. Specific protocols were designed for each enzyme since temperature and immobilization period revealed to be important parameters, which must be tightly regulated in order to obtain more stable derivatives. The immobilized enzymes were highly stabilized in wide $\mathrm{pH}$ range presenting much more stability than the free enzyme. Immobilized BXYL II is more stable at high temperatures than BXYL I, while immobilized BXYL I is much more stable under long-term incubation. The derivatives present promising characteristics, such as high stability, offering advantages over the free enzyme. Due to the long-term stability and operational stability, BXYL I glyoxyl derivative is proposed to be jointly used with a previously developed biocatalyst containing co-immobilized xylanase, $\beta$-xylosidase, and $\alpha$-arabinofuranosidase activities for the complete degradation of arabinoxylans.

Acknowledgements This work was partially sponsored by FAPESP (Project 2010/16582-0) and the Spanish Ministry of Science and Innovation (Project BIO-2012-36861). C.R.F.T. gratefully acknowledges PROPe/ UNESP and CAPES/Ministry of Education, Brazil, through the Program Science Without Borders for the postdoctoral scholarship (3134-13-0).

\section{Compliance with Ethical Standards}

Conflict of Interest The authors declare that they have no conflict of interest.

\section{References}

1. Dodd, D., \& Cann, I. K. O. (2009). Enzymatic deconstruction of xylan for biofuel production. Global Change Biology. Bioenergy, 1(1), 2-17. doi:10.1111/j.1757-1707.2009.01004.x.

2. Jordan, D. B., \& Wagschal, K. (2010). Properties and applications of microbial $\beta$-D-xylosidases featuring the catalytically efficient enzyme from Selenomonas ruminantium. Applied Microbiology and Biotechnology, 86(6), 1647-1658. doi:10.1007/s00253-010-2538-y.

3. Zhang, J., \& Viikari, L. (2012). Xylo-oligosaccharides are competitive inhibitors of cellobiohydrolase I from Thermoascus aurantiacus. Bioresource Technology, 117, 286-291. doi:10.1016/j.biortech.2012.04.072.

4. Dhiman, S. S., Sharma, J., \& Battan, B. (2008). Industrial applications and future prospects of microbial xylanases: a review. BioResources, 3(4), 1377-1402.

5. Deutschmann, R., \& Dekker, R. F. H. (2012). From plant biomass to bio-based chemicals: latest developments in xylan research. Biotechnology Advances, 30(6), 1627-1640. doi:10.1016/j. biotechadv.2012.07.001.

6. Goswami, G., \& Pathak, R. (2013). Microbial xylanases and their biomedical applications: a review. International Journal of Basic \& Clinical Pharmacology, 2(3), 237. doi:10.5455/2319-2003. ijbcp20130602. 
7. Juturu, V., \& Wu, J. C. (2012). Microbial xylanases: engineering, production and industrial applications. Biotechnology Advances, 30(6), 1219-1227. doi:10.1016/j.biotechadv.2011.11.006.

8. Polizeli, M. L. T. M., Rizzatti, A. C. S., Monti, R., Terenzi, H. F., Jorge, J. A., \& Amorim, D. S. (2005). Xylanases from fungi: properties and industrial applications. Applied Microbiology and Biotechnology, 67(5), 577-591. doi:10.1007/s00253-005-1904-7.

9. Cragg, S. M., Beckham, G. T., Bruce, N. C., Bugg, T. D. H., Distel, D. L., Dupree, P., \& Zimmer, M. (2015). Lignocellulose degradation mechanisms across the tree of life. Current Opinion in Chemical Biology, 29, 108-119. doi:10.1016/j.cbpa.2015.10.018.

10. Homaei, A. A., Sariri, R., Vianello, F., \& Stevanato, R. (2013). Enzyme immobilization: an update. Journal of Chemical Biology, 6(4), 185-205. doi:10.1007/s12154-013-0102-9.

11. Knob, A., Terrasan, C. R. F., \& Carmona, E. C. (2010). $\beta$-Xylosidases from filamentous fungi: an overview. World Journal of Microbiology and Biotechnology, 26(3), 389-407. doi:10.1007/s11274-009-0190-4.

12. Fernandez-Lafuente, R. (2009). Stabilization of multimeric enzymes: strategies to prevent subunit dissociation. Enzyme and Microbial Technology, 45(6-7), 405-418. doi:10.1016/j.enzmictec.2009.08.009.

13. Aragon, C. C., Mateo, C., Ruiz-Matute, A. I., Corzo, N., Fernandez-Lorente, G., Sevillano, L., \& Guisan, J. M. (2013). Production of xylo-oligosaccharides by immobilized-stabilized derivatives of endo-xylanase from Streptomyces halstedii. Process Biochemistry, 48(3), 478-483. doi:10.1016/j. procbio.2013.01.010.

14. Driss, D., Haddar, A., Ghorbel, R., \& Chaabouni, S. E. (2014). Production of xylooligosaccharides by immobilized His-tagged recombinant xylanase from Penicillium occitanis on nickel-chelate Eupergit C. Applied Biochemistry and Biotechnology, 173(6), 1405-1418. doi:10.1007/s12010014-0932-0.

15. Liu, M., Huo, W., Xu, X., \& Jin, D. (2015). An immobilized bifunctional xylanase on carbon-coated chitosan nanoparticles with a potential application in xylan-rich biomass bioconversion. Journal of Molecular Catalysis B: Enzymatic, 120, 119-126. doi:10.1016/j.molcatb.2015.07.002.

16. Terrasan, C. R. F., Aragon, C. C., Masui, D. C., Pessela, B. C., Fernandez-Lorente, G., Carmona, E. C., \& Guisan, J. M. (2016). $\beta$-xylosidase from Selenomonas ruminantium: immobilization, stabilization and application for xylooligosaccharide hydrolysis. Biocatalysis and Biotransformation (in print).

17. Terrasan, C. R. F., Temer, B., Duarte, M. C. T., \& Carmona, E. C. (2010). Production of xylanolytic enzymes by Penicillium janczewskii. Bioresource Technology, 101(11), 4139-4143. doi:10.1016/j. biortech.2010.01.011.

18. Temer, B., Terrasan, C. R. F., \& Carmona, E. C. (2014). $\alpha$-L-arabinofuranosidase from Penicillium janczewskii: production with brewer's spent grain and orange waste. African Journal of Biotechnology, 13(17), 1796-1806. doi:10.5897/AJB2013.13361.

19. Terrasan, C. R. F., Guisan, J. M., \& Carmona, E. C. (2016). Xylanase and $\beta$-xylosidase from Penicillium janczewskii: purification, characterization and hydrolysis of substrates. Electronic Journal of Biotechnology, 19(5), 54-62. doi:10.1016/j.ejbt.2016.08.001.

20. Terrasan, C. R. F., Trobo-Maseda, L., Moreno-Pérez, S., Carmona, E. C., Pessela, B. C., \& Guisan, J. M. (2016). Co-immobilization and stabilization of xylanase, $\beta$-xylosidase and $\alpha$-L-arabinofuranosidase from Penicillium janczewskii for arabinoxylan hydrolysis. Process Biochemistry, 51(5), 614-623. doi:10.1016/j. procbio.2016.02.014.

21. Kersters-Hilderson, H., Claeyssens, M., Van Doorslaer, E., Saman, E., \& De Bruyne, C. K. (1982). Complex Carbohydrates Part D. Methods in Enzymology, vol 83. Elsevier. doi:10.1016/0076-6879(82)83062-0.

22. Lowry, O. H., Rosebrough, N. J., Farr, A. L., \& Randall, R. J. (1951). Protein measurement with the Folin phenol reagent. The Journal of Biological Chemistry, 193(1), 265-275.

23. Laemmli, U. K. (1970). Cleavage of structural proteins during the assembly of the head of bacteriophage T4. Nature, 227(5259), 680-685. doi:10.1038/227680a0.

24. Mateo, C., Palomo, J. M., Fuentes, M., Betancor, L., Grazu, V., López-Gallego, F., \& Guisán, J. M. (2006). Glyoxyl agarose: a fully inert and hydrophilic support for immobilization and high stabilization of proteins. Enzyme and Microbial Technology, 39(2), 274-280. doi:10.1016/j.enzmictec.2005.10.014.

25. Fernandez-Lafuente, R., Rosell, C. M., Rodriguez, V., Santana, C., Soler, G., Bastida, A., \& Guisán, J. M. (1993). Preparation of activated supports containing low pK amino groups. A new tool for protein immobilization via the carboxyl coupling method. Enzyme and Microbial Technology, 15(7), 546-550. doi:10.1016/0141-0229(93)90016-U.

26. Mateo, C., Pessela, B. C. C., Fuentes, M., Torres, R., Betancor, L., Hidalgo, A., \& Guisan, J. M. (2006). Stabilization of multimeric enzymes via immobilization and further cross-linking with aldehyde-dextran. 22, 129-41. doi:10.1007/978-1-59745-053-9_12.

27. Fernandez-Lafuente, R., Rosell, C. M., Rodriguez, V., \& Guisan, J. M. (1995). Strategies for enzyme stabilization by intramolecular crosslinking with bifunctional reagents. Enzyme and Microbial Technology, 17(6), 517-523. doi:10.1016/0141-0229(94)00090-E. 
28. Betancor, L., López-Gallego, F., Alonso-Morales, N., Dellamora, G., Mateo, C., Fernandez-Lafuente, R., \& Guisan, J. (2006). Glutaraldehyde in protein immobilization. In J. M. Guisan (Ed.), Immobilization of enzymes and cells SE - 5, vol 22 (pp 57-64). Humana Press. doi:10.1007/978-1-59745-053-9 5.

29. Ito, T., Yokoyama, E., Sato, H., Ujita, M., Funaguma, T., Furukawa, K., \& Hara, A. (2003). Xylosidases associated with the cell surface of Penicillium herquei IFO 4674. Journal of Bioscience and Bioengineering, 96(4), 354-359. doi:10.1016/S1389-1723(03)90136-8.

30. Wakiyama, M., Yoshihara, K., Hayashi, S., \& Ohta, K. (2008). Purification and properties of an extracellular $\beta$-xylosidase from Aspergillus japonicus and sequence analysis of the encoding gene. Journal of Bioscience and Bioengineering, 106(4), 398-404. doi:10.1263/jbb.106.398.

31. Knob, A., \& Carmona, E. C. (2011). Purification and properties of an acid $\beta$-xylosidase from Penicillium sclerotiorum. Annals of Microbiology, 62(2), 501-508. doi:10.1007/s13213-011-0282-x.

32. Díaz-Malváez, F. I., García-Almendárez, B. E., Hernández-Arana, A., Amaro-Reyes, A., \& RegaladoGonzález, C. (2013). Isolation and properties of $\beta$-xylosidase from Aspergillus niger GS1 using corn pericarp upon solid state fermentation. Process Biochemistry, 48(7), 1018-1024. doi:10.1016/j. procbio.2013.05.003.

33. Nieto-Domínguez, M., de Eugenio, L. I., Barriuso, J., Prieto, A., Fernández de Toro, B., CanalesMayordomo, A., \& Martínez, M. J. (2015). Novel pH-stable glycoside hydrolase family $3 \beta$-xylosidase from Talaromyces amestolkiae: an enzyme displaying regioselective transxylosylation. Applied and Environmental Microbiology, 81(18), 6380-6392. doi:10.1128/AEM.01744-15.

34. Rizzatti, A. C., Jorge, J. A., Terenzi, H. F., Rechia, C. G., \& Polizeli, M. L. (2001). Purification and properties of a thermostable extracellular beta-D-xylosidase produced by a thermotolerant Aspergillus phoenicis. Journal of Industrial Microbiology \& Biotechnology, 26(3), 156-160. doi:10.1038 /sj/jim/7000107.

35. Lenartovicz, V., Marques De Souza, C. G., Guillen Moreira, F., \& Peralta, R. M. (2003). Temperature and carbon source affect the production and secretion of a thermostable $\beta$-xylosidase by Aspergillus fumigatus. Process Biochemistry, 38(12), 1775-1780. doi:10.1016/S0032-9592(02)00261-3.

36. Matsuo, M., Fujie, A., Win, M., \& Yasui, T. (1987). Four types of beta-xylosidases from Penicillium wortmanni IFO 7237. Agricultural and Biological Chemistry, 51(9), 2367-2379. doi:10.1271 /bbb1961.51.2367.

37. Kumar, S., \& Ramón, D. (1996). Purification and regulation of the synthesis of a $\beta$-xylosidase from Aspergillus nidulans. FEMS Microbiology Letters, 135(2-3), 287-293. doi:10.1111/j.1574-6968.1996. tb08003.x.

38. Bolivar, J. M., Wilson, L., Ferrarotti, S. A., Fernandez-Lafuente, R., Guisan, J. M., \& Mateo, C. (2006). Stabilization of a formate dehydrogenase by covalent immobilization on highly activated glyoxyl-agarose supports. Biomacromolecules, 7(3), 669-673. doi:10.1021/bm050947z.

39. Jordan, D. B., Li, X. L., Dunlap, C. A., Whitehead, T. R., \& Cotta, M. A. (2007). $\beta$-D-xylosidase from Selenomonas ruminantium of glycoside hydrolase family 43. Applied Biochemistry and Biotechnology, 137-40, 93-104. doi:10.1007/s12010-007-9042-6. 